\title{
ASSESSMENT OF DEBT COUNSELLING SERVICES: a CASE OF GAUTEng, SOUTH Africa
}

\author{
Kgomotso H Masilo* \\ Tshwane University of Technology \\ masilokh@tut.ac.za
}

Received: March 2015

\author{
Johan Marx" \\ University of South Africa \\ marxj@unisa.ac.za
}

Accepted: September 2015

\begin{abstract}
The high level of over-indebtedness in Gauteng is cause for concern. The number of consumers applying for debt counselling as well as the registered debt counsellors is increasing. The study on which this article reports aimed at exploring and describing the role of debt counselling in terms of personal financial well-being of consumers in Gauteng. Fifteen debt counsellors were interviewed and 300 consumers were surveyed. Data was analysed using descriptive statistics. There was no evidence that consumers who received debt counselling improved in their financial standing. It was observed that both debt counsellors and consumers lacked financial management skills. It was concluded that, while debt counselling is important, it does not necessarily improve the financial well-being of consumers. It is recommended that financial management skills should serve as a pre-requisite for debt counselling registration and consumers be introduced to personal financial management education at an early stage of their lives.
\end{abstract}

Keywords

Personal financial management, financial well-being, over-indebtedness, debt counselling, Gauteng.

*Dr KH Masilo is a lecturer in the Department of Management and Entrepreneurship, Tshwane University of Technology, South Africa.

\#Prof J Marx is professor in the Department of Finance, Risk Management and Banking, University of South Africa, South Africa. 


\section{INTRODUCTION}

South African consumers are struggling with their personal financial well-being because of too much debt and bad financial planning (Consumer Financial Vulnerability Index for South Africa, 2013). Individuals find themselves spending more than they earn (Cameron, 2012), which results in individuals becoming over-indebted. According to De Waal (2013), South Africa's exposure to credit in the private domestic sector was R230 billion in 1994 and has increased to R2.1 trillion in 2012.

A significant number of consumers use much of their disposable income to service debt, while the unsecured lending is also driving the debt spiral (Bester, 2013). With offers of quick, easy and large amounts of money available from financial institutions, consumers feel the pinch. There are a growing number of consumers falling into arrears on their debt payments (De Waal, 2013). Consumers are therefore resorting to debt counselling for assistance and protection.

Gauteng, one of the nine provinces of South Africa, has a high number of households in comparison with the other provinces (Stats SA, 2012). Geographically the province has the smallest land surface; however, it constitutes the dominant part of the South African economy. By the end of the fourth quarter of 2012, the total value of credit granted in all provinces increased, with Gauteng being granted R51.32 billion ( $46.77 \%$ of the national figure), which was much higher than any other province (NCR, 2012).

At the time this study was undertaken (2012), Gauteng had 1001 registered debt counsellors out of a total of 2048 debt counsellors registered nationally. This means that Gauteng had approximately $50 \%$ of the total registered debt counsellors in South Africa (NCR, 2014). The number of consumers seeking debt counselling assistance increased from 12574 in May 2008 to 412918 in May 2013 (NCR, 2014), and more than 50\% of these consumers resided in Gauteng.

Various reports (Business Enterprises, 2012; Daily Industry News, 2012) show growing concern about lending patterns, debt enforcement procedures and practices, debt rehabilitation and consumer vulnerability in South Africa. In addition, most studies previously conducted on debt counselling focused on the legal impact of the National Credit Act No. 34 of 2005 (dti, 2003; Roestoff, Haupt, Coetzee \& Erasmus, 2009), and very little, if any, empirical research has been done on the role of debt counselling in the financial well-being of consumers in South Africa.

It is against this background that the authors of this article aim to close this gap and contribute to the existing literature by exploring and describing the role played by debt counselling in the financial well-being of consumers in Gauteng.

The purpose of the study was two-fold. Firstly, the study attempted to assess the role of debt counselling services provided by debt counsellors to consumers. Secondly, the study had to assess whether debt counselling had a positive effect on the personal financial well-being of consumers who participated in the debt counselling process. To reach this goal, a two-phased sequential design, which started with the qualitative approach followed by the quantitative approach, was used.

The rest of the article proceeds as follows: section 2 provides a theoretical analysis of both the personal financial management and the role of debt counselling in the lives of consumers. Section 3 discusses the methodology used in this study. Section 4 presents the analysis and the discussion of results. The recommendations follow in section 5 , while the conclusion is presented in section 6. 


\section{LITERATURE REVIEW}

The debt management practices of South African consumers give the impression that personal finances are inadequately managed and that consumers end up with excessive debts. As a result, consumers resort to debt counselling (Daily Industry News, 2012). It is against this background that this section focuses on two conceptual frameworks within which personal financial management and the role of debt counselling are discussed.

\subsection{Personal financial management}

Personal financial management is described firstly as a means of ensuring a reasonable balance between outflow and inflow of an individual's funds, and, secondly, as a technique of reducing the uncertainties with regard to changing market trends (MSG, 2013).

Each year, millions of households in South Africa find themselves overwhelmed by debt (De Waal, 2013) and struggling to maintain their monthly payments. Theobald and Dick (2013) indicate that unsecured lending has grown from R7 billion in 2008 to R29 billion in 2012, with loans of longer than three years increasing from $30 \%$ to $62 \%$, and loans of more than R15 000 increasing from $42 \%$ to $78 \%$ during the same period. They also indicate that the unsecured lending market is dependent on indebted consumers who need to keep paying their instalments on larger, long-term loans.

Unsecured loans or 'signature loans' are becoming popular to consumers because banks issue them without attaching any collateral, requiring only the individual's signature (Pritchard, 2013). According to Bailey (2013), South African consumers are experiencing financial difficulties because of the unsustainable increase in payday loans and the unsecured loans that are offered by the banks. The amounts of unsecured loans and the repayment terms offered by the South African banks are illustrated in TABLE 1 .

TABLE 1: Amounts of unsecured loans and repayment terms

\begin{tabular}{lcc}
\hline Bank & $\begin{array}{c}\text { Maximum amount that can be } \\
\text { offered }\end{array}$ & Maximum repayment term \\
\hline ABSA & R150000 & 84 months \\
Standard Bank & R120000 & 42 months \\
Nedbank & R120000 & 60 months \\
FNB & R150000 & 60 months \\
African Bank & R180000 & 84 months \\
Capitec & R230000 & 84 months \\
\hline
\end{tabular}

Source: Moneyweb (2013)

Personal financial management can assist individuals to be independent and be able to handle unpredictable events (Dialtax, 2012). According to National Credit Act Info (2012), retirement, changes in the labour market and personal income are some of the reasons why individuals should learn about personal finance. Retirement planning has become more crucial with the nature of employment changing in the developing open economy (Viswanand, 2013). Job security and the notion of work keep on changing. Self-employment has increased, and contractual employment 
has become more common as it has productivity-linked terms of employment (Viswanand, 2013). The individual's personal financial knowledge coupled with his or her goals, income and desire will all combine to define that person's wealth picture (Wealth-Steps.com, 2012).

FIGURE 1 illustrates that personal financial planning is guided by personal goals which might be short-term, long-term, monetary and non-monetary. In addition, the external factors that include government actions and economic conditions that may affect personal financial decisions should be considered (Boone, Kurtz \& Hearth, 2000:7).

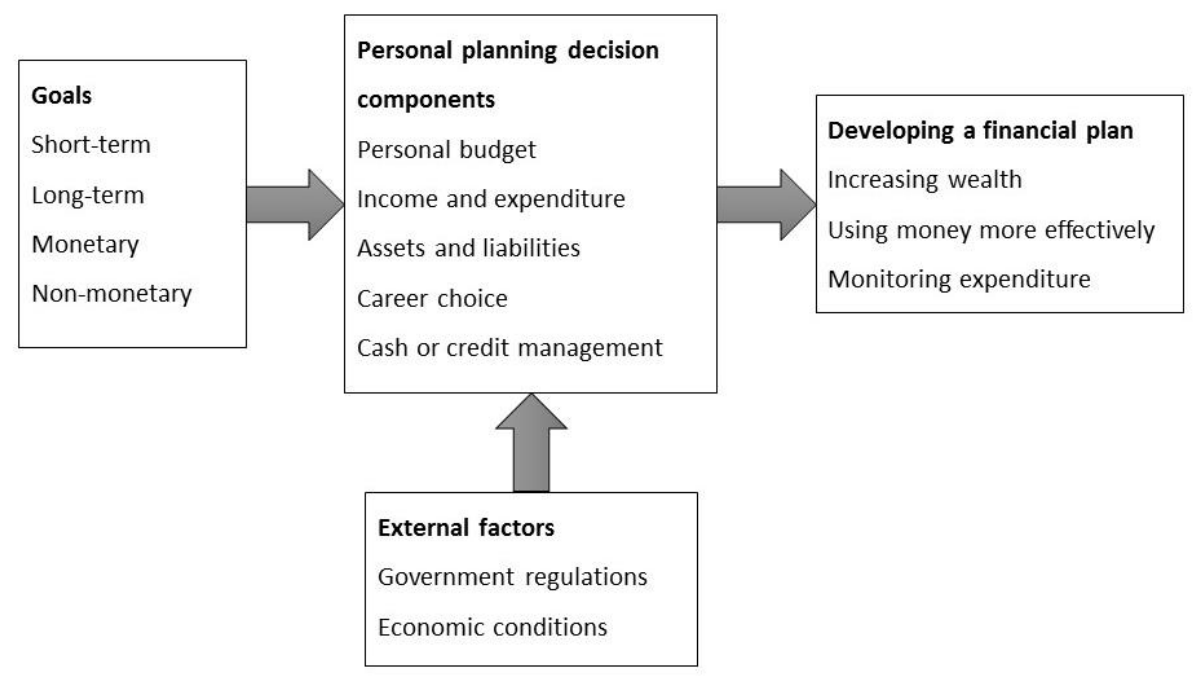

\section{FIGURE 1: Personal financial planning model}

Source: Boone et al. (2000)

Although individuals cannot change the external factors, they can make personal decisions about things such as their personal budgets, income and expenditure; assets and liabilities; career choices and whether to pay cash for goods or buy on credit (FIGURE 1).

Personal financial planning provides an individual with a method for organising his or her financial future, so that he or she can plan for any unforeseen circumstances. Setting attainable, measurable goals is the first thing that an individual needs to do in order to achieve financial security. Understanding personal finance is important for individuals irrespective of the life stage in which they may be (National Credit Act Info, 2012). At key life stages, individuals are faced with wants and needs that may exceed their earnings and savings (Gordon, 2010). For example, when buying a house or a car, people are often forced to borrow money and take on debt (Gordon, 2010). Debt can enhance wealth or destroy wealth depending upon how it is used, but in South Africa, consumer debt has proved to be a disaster (De Waal, 2013).

Family Economics and Financial Education (2010) pointed out that financial needs change throughout the individual's lifecycle. According to Serrano (2012), a personal financial planning lifecycle consists of following three stages. 


\section{Stage 1: Basic wealth protection or asset accumulation stage}

This is the family formation stage for many individuals. This stage generally starts around the age of 20 and it can last until the age of 35 (Serrano, 2012). During this stage, an individual starts to find a job or a career, starts to earn money, builds up assets, continues with his or her education, starts to make use of credit, starts a family and/or maximises net worth. At this stage, the individual should be focusing on building financial security (Serrano, 2012).

\section{Stage 2: Conservation and protection stage}

The second stage goes beyond financial security, and signifies the time when an individual starts to reward him or herself. This stage can start as early as the individual's late 30 s and usually lasts throughout his or her $40 \mathrm{~s}$ and $50 \mathrm{~s}$. This stage begins when individuals start to have assets that they feel are worth protecting. The stage is usually characterised by an increase in cash flow or high levels of debt, assets and net worth for some individuals, while for other individuals, the use of credit starts to decrease. As more assets are accumulated, individuals become more risk adverse. They are concerned about losing what they have already accumulated. During this stage, individuals are usually more aware of financial risks, such as loss of a job, loss of life or disability and they are therefore interested in saving for retirement and possibly for their children's education (Serrano, 2012).

\section{Stage 3: Gifting and wealth distribution stage}

The last stage involves 'giving the money to an individual's chosen ones'. This stage involves the consumption of wealth, usually during retirement, and is usually achieved in the late 50 s and early $60 \mathrm{~s}$, but could start earlier depending on the person's wealth. This stage occurs when individuals realise that they can spend money on things they never thought possible. During this stage, individuals have excess cash flow, high net worth, and low or even no debt, and they are also very aware of financial risks and have established security against losses. Some issues of high concern would be gifting tax and estate taxes (Serrano, 2012).

According to the Consumer and Financial Literacy Taskforce (2010), as individuals progress through life, they also acquire a degree of skill in the way they use and manage money. Moreover, individuals with greater financial knowledge are more likely to accumulate wealth (Lusardi \& Mitchell, 2006).

However, the financial lifecycles of some people are often disrupted by unexpected events, which may encourage individuals to buy on credit and ultimately face debt problems and bankruptcy. Norvilitis, Merwin, Osberg, Roehling, Young and Kamas (2006) emphasise that individuals who lack financial literacy demonstrate poor financial decision-making ability as well as increased levels of debt. When individuals encounter problems related to debt repayment or when they experience credit-related problems, they may consult debt counsellors for assistance and protection (Wang, 2010:47).

\subsection{The role of debt counselling}

Debt counselling was introduced in South Africa to provide a process for helping consumers who encounter problems with debt repayment by providing services such as reduced monthly repayments, protection from legal action and after-care. Consumers who experience debt repayment problems may seek assistance with restructuring their debt by applying for a debt counselling service at any debt counsellor of their choice. The debt counsellor has to explain all 
the details pertaining to the debt counselling process to a consumer before any debt counselling application and agreement form is signed (Debt Counselling Help South Africa, 2009).

Debt counselling is a professional service that employs the services of the payment distribution agencies (PDAs) to assist consumers to honour their periodic debt obligations (De Wet, 2011). The relationships that debt counsellors have with the PDAs seem beneficial in assisting consumers pay their debts (NCR, 2013). The payments that were distributed to the credit providers between 2008 and 2013 are illustrated in FIGURE 2. Without debt counselling, these consumers would not have had any recourse to an independent mechanism to assist them.

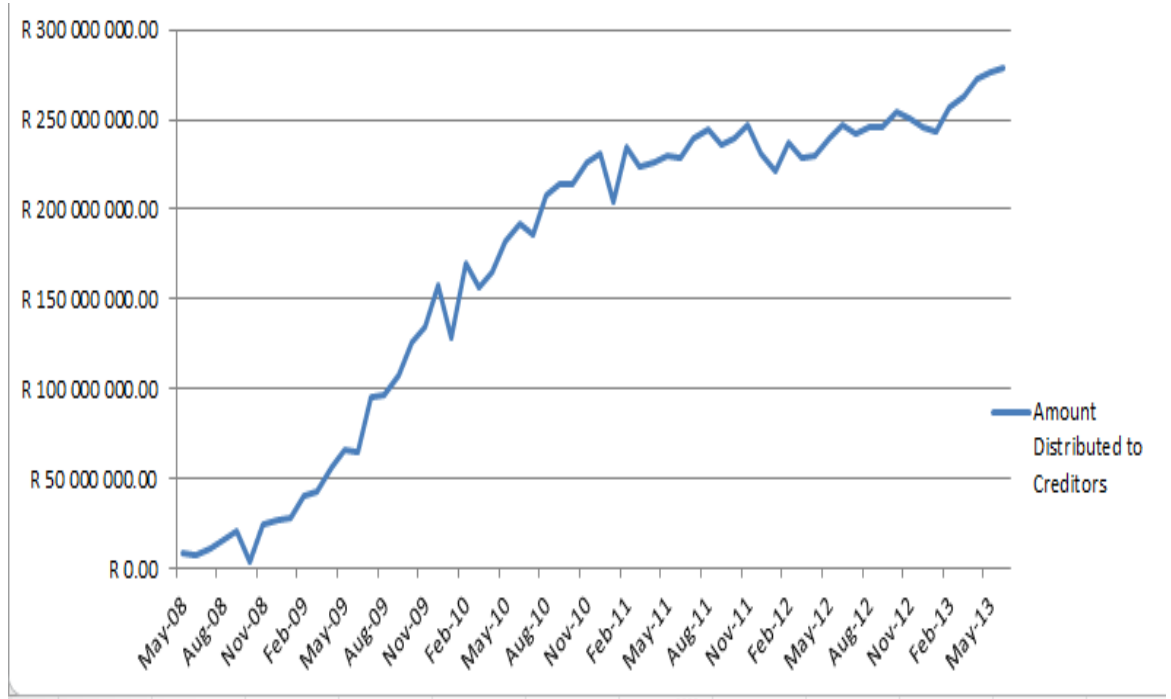

\section{FIGURE 2: Payments distributed by PDAs to creditors from 2008 to 2013}

Source: Adapted from NCR (2014)

Although debt counselling services in South Africa have been a primary debt relief remedy for over-indebted consumers; they still need standardisation and acceptance amongst credit providers and debt counsellors (Business Enterprises, 2012). Some credit providers have neither the capacity nor the appropriate policies and procedures to respond adequately to debt restructuring proposals and, as a result, backlogs in the debt counselling process are experienced (Davel, 2010).

Since its inception, according to Groenewald (2010), the debt counselling process has been plagued by challenges and obstacles. The levels of competencies of debt counsellors, education and experience in the debt review have been identified as some of the barriers for effective debt counselling process. In assessing the preparedness of the debt counsellors before they start with debt review process, Groenewald (2010) undertook an intensive study to determine the competency requirements and skills needed for the debt counsellors. The findings revealed that some debt counsellors were incompetent, lacked integrity and knowledge of financial management as well as knowledge of credit legislation.

Business Enterprises (2012) also indicated that the two-week course that debt counsellors undergo as a pre-requisite for their registration is based only on theoretical aspects of debt 
counselling. The course does not empower debt counsellors to deal with complex administrative tasks; neither does it equip debt counsellors with financial management skills.

\section{RESEARCH METHODOLOGY}

A two-phased sequential design, which started with the qualitative approach followed by the quantitative approach, was used. Subsections 3.1 and 3.2 discuss how the population and sampling was selected, and how data collection was conducted.

\subsection{Population and sampling}

Gauteng had 1001 registered debt counsellors in 2012. Seventy per cent of these debt counsellors reside and operate in the three metropolitan municipalities of Gauteng. The three municipalities are City of Johannesburg, City of Tshwane and Ekurhuleni. The population for the first phase (qualitative) of the study therefore comprised debt counsellors in these three municipalities.

Due to the fact that it was not possible to conduct a census with the population of 701 ( $70 \%$ of 1001 ) debt counsellors, and for equal representation from the three selected municipalities, a purposeful sampling method (Creswell, 2007:125) was used to select a sample of five debt counsellors from each of the three selected municipalities to make a sample of $15 \mathrm{debt}$ counsellors.

The population for the second phase (quantitative) comprised all consumers who received debt counselling services (between 2008 and 2011) from the 15 debt counsellors who were selected for the first phase. A snowball non-probability sampling technique (Welman, Kruger \& Mitchell, 2010) was used to select a sample. Each debt counsellor selected was requested to identify and send questionnaires to 20 consumers who received debt counselling services from them, making a total sample of $300(15 \times 20)$ consumers.

\subsection{Data collection}

There were two phases for data collection. Phase one comprised semi-structured interviews with debt counsellors. These interviews sought to assess the role of debt counselling services provided by debt counsellors to consumers. The interviews were recorded and later transcribed verbatim. Responses from the interviews formed the qualitative data.

For trustworthiness of data from interviews, transcripts were taken back to the debt counsellors to verify whether the transcriptions reflected their intended views. A few semantic changes were made to the satisfaction of the debt counsellors.

Phase two comprised a self-developed 5-point Likert-type scale questionnaire. Three hundred questionnaires were administered to consumers who participated in the debt counselling process in order to assess whether debt counselling had a positive effect on their personal financial wellbeing. Only 182 completed questionnaires were returned, giving a response rate of $61 \%$. The validity of the questionnaire was assessed by means of exploratory factor analysis (Grayson, 2004). 


\section{DATA ANALYSIS AND DISCUSSION OF RESULTS}

Data was analysed in two phases: qualitative analysis and quantitative analysis. The analysis and the discussion follow in subsections 4.1 and 4.2.

\subsection{Qualitative analysis}

The qualitative data was analysed thematically using the Atlas.ti software. Themes that emerged were: consumers' financial well-being, guidelines for debt counselling process, documents for debt counselling application, duration of debt counselling, intervention methods, support from the NCR and mechanisms used to verify the financial well-being of clients. Results gathered from these themes are discussed in the next section.

Based on the responses gathered from the debt counsellors interviewed, $73 \%$ blacks and $57 \%$ males from Gauteng applied for debt counselling service between 2008 and 2011. In addition, the debt counsellors indicated that most of their clients were working, earning a salary, and had acquired unsecured debts from various financial institutions due to expensive lifestyles and a lack of financial management knowledge. Groceries and rent were also identified as major expenditure items.

Furthermore, debt counsellors stated that they used prescribed guidelines in conducting debt counselling processes, although it was noticeable that they did not necessarily follow them in the prescribed order. It was also indicated that individuals need to submit their payslips, identity documents, latest statements from credit providers, proof of residence and three-month bank statements when applying for debt counselling. The duration of the debt counselling process depends entirely on the amount that the over-indebted client owes, but should not exceed five years.

It was noted that most debt counsellors (between $47 \%$ and $53 \%$ ) use the provision of after-care or a moral support method and reviewing of accounts of their clients as their intervention methods. Debt counsellors also indicated that they did not collect money from their clients but hand their clients over to the PDAs for monthly payment collections. Though most of the debt counsellors (67\%) agreed that they received support from the NCR, few debt counsellors (33\%) indicated with reasons their dissatisfaction regarding the support from the NCR. It was indicated that the NCR was not appropriately monitoring the activities of some of the credit providers; neither was it responding to complaints raised by some of the debt counsellors. Furthermore, debt counsellors pointed out that the NCR takes time to register the transfer of consumers from one debt counsellor to another, and to issue clearance certificates to consumers who have paid their debts in full.

The majority of the debt counsellors interviewed (87\%) acknowledged that they did not have financial management qualifications and that they did not have any mechanisms that they use to verify the financial well-being of their clients after debt counselling. The followings conclusions were arrived at:

a. Though most of the over-indebted consumers were working and earning a salary, they did not necessarily know how to manage their finances. They did not have fixed assets that could be used as collateral (security) and hence resorted to unsecured lending.

b. Most of the debt counsellors lacked financial management knowledge. 
c. The moral support and the reviewing of accounts by the participating debt counsellors were not sufficient methods for intervention.

d. The NCR needs to monitor and support all debt counsellors continuously for proper delivery of the debt counselling service.

The results from the quantitative study are analysed in the next subsection.

\subsection{Puantitative analysis}

The quantitative data was analysed by making use of Statistical Package for Social Sciences (SPSS) version 22.0 software. Results obtained were analysed, interpreted and presented by making use of both tables and a graph.

In testing the convergent validity of the constructs, exploratory factor analysis (EFA) was employed, firstly to determine whether each question contributes to the respective constructs as contained in the questionnaire, and, secondly, to identify the hidden dimensions or constructs which may or may not be noticeable from direct analysis.

TABLE 2: Principal component analysis - Rotated component matrix

\begin{tabular}{|c|c|c|c|}
\hline & \multicolumn{3}{|c|}{ Factors } \\
\hline & 1 & 2 & 3 \\
\hline SecCQ10 & & .705 & \\
\hline SecCQ11 & & .837 & \\
\hline SecCp13 & & .796 & \\
\hline SecCP14 & & .645 & \\
\hline SecDQ16 & .716 & & \\
\hline SecDQ17 & .808 & & \\
\hline SecDQ18 & .706 & & \\
\hline SecDQ19 & .705 & & \\
\hline SecDQ20 & .792 & & \\
\hline SecDQ21 & .559 & & \\
\hline SecE९22 & .678 & & \\
\hline $\operatorname{Sec} \varepsilon \Longleftrightarrow 23$ & .779 & & \\
\hline SecE९24 & & & .832 \\
\hline SecEQ25 & & & .799 \\
\hline SecEQ26 & & & .849 \\
\hline SecEQ27 & & & .633 \\
\hline \multicolumn{4}{|c|}{$\begin{array}{l}\text { Extraction method: Principal component analysis. } \\
\text { Rotation method: Varimax with Kaiser normalization. }\end{array}$} \\
\hline a. Rotation c & & & \\
\hline
\end{tabular}

Source: Authors' analysis 
The Bartlett's test of sphericity and the Kaizer-Meyer-0lkin (KMO) measure of sampling adequacy are two statistical measures to assess the factorability of the data (Pallant, 2010). Based on calculations the sample was adequate, because the KMO measure yielded a value of 0.835 , which is a good value (Wright, 2003:123). The data also proved to be suitable for factor analysis because the Bartlett's test was below 0.05 (Wright, 2003:123).

The factor analysis identified three factors from the data, meaning that there were three underlying dimensions which were identified as separate factors that relate to the role of debt counselling service in the financial well-being of consumers in Gauteng. Factor 1 dealt with effectiveness of the debt counselling process (ETDC), factor 2 had to do with the debt counselling process (DCP) and factor 3 related to the effect of debt counselling (EDC). The results of factor analysis are summarised in TABLE 2 .

The rotated factor matrix converged and iterated all the constructs. After the iterations, the principal analysis discarded three questions ( $(12,015$ and $Q 28)$ because they did not fit well. These three questions did not load on any of the factors due to paucity of validity. Two more questions ( 222 and Q23) were also transferred from factor 3 (EDC) to factor 1 (ETDC).

The study also employed principal component analysis as the method of extraction. The total factors explained a variance of $64.91 \%$, which exceeded the required threshold of 0.60 (Thekiso, $2011: 248$ ), to represent a good fit to the data. This means that the validity of the data was verified to suit the questionnaire correctly. Catell's scree test (Pallant, 2010:155) was used to plot each of the eigenvalues of the factors and to inspect the plot to find a point at which the shape of the curve changed direction and became horizontal.

The demographic profile of the respondents (consumers) indicated that there were more females (57\%) than males (43\%) from Gauteng who received debt counselling services and that the majority of the respondents were between the ages of 40 and 49 years. Sixty-three per cent were blacks, $22 \%$ were whites, and the coloureds and Indians/Asians were $12 \%$ and $3 \%$ respectively. With regard to education, $41 \%$ of the respondents had passed matric and $36 \%$ passed a postmatric qualification, while the rest did not have matric. In addition, more than half (51\%) of the respondents were married, while $31.9 \%$ were single and the rest were either divorced or widowed.

Although the majority of the respondents (more than 90\%) agreed that it was easy for them to apply for debt counselling and that they were informed about the debt counselling process, debt counselling gave them peace of mind, debt counselling prevented their assets from being repossessed, an affordable and manageable monthly repayment was arranged for all their debts (even though the amount they owed increased due to interest charged) and they paid a single amount to PDAs every month, only 33\% strongly agreed that debt counselling taught them to manage their finances, $19.8 \%$ strongly agreed that they were able to save money, $13.2 \%$ and $16.5 \%$ strongly agreed to the fact that their names were removed from the credit bureau and that they received clearance certificates respectively. However, $11.5 \%$ of the respondents strongly agreed that debt counselling re-instated their creditworthiness.

The following conclusions were arrived at:

a. Most consumers become over-indebted when they are between the ages of 40 and 49 years. This confirms the financial planning lifecycle (Serrano, 2012).

b. Although some of the respondents were pleased with the service they obtained from the debt counsellors, some were discontent because their debts were increased, their names were not 
expunged from the credit bureaux, they were not sure whether they could manage their finances well and they had not received their clearance certificates.

Following from the analysis of the results, several recommendations were suggested and they are indicated in the next section.

\section{RECOMMENDATION}

To enhance proper debt counselling and ultimately personal financial management skills, the study proposes recommendations for the debt counsellors, the consumers, the NCR and lastly for further research.

\subsection{Recommendations for the debt counsellors}

The results also signified that debt counsellors had insufficient intervention methods to assist their clients during the debt counselling process and that debt counsellors lacked financial management skills and mechanisms that they could employ to verify their clients' financial wellbeing after the debt counselling service. In addition, it was pointed out that some consumers struggled to receive their clearance certificates and getting their names expunged from the credit bureaux after paying off their debts.

It is therefore recommended that:

a. Debt counsellors should include and conduct personal financial management lessons to their clients as part of their intervention methods. They should set a period to assess their clients' conduct of the running of their personal financial matters after debt counselling process, as a mechanism for the clients' financial position verification.

b. Debt counsellors should acquire financial management skills prior to registering as debt counsellors.

c. Debt counsellors should be compelled to submit the names of their rehabilitated clients to the NCR for immediate issuing of the clearance certificates and to the credit bureaux for credit rating changes.

\subsection{Recommendations for the consumers}

The results indicated that the over-indebted consumers were working and earning a salary, but, unfortunately, they were spending more than they were earning. These consumers did not have the ability to prioritise their expenses. It was also identified that because they did not have fixed assets, they resorted to unsecured lending, which is easily accessible from unscrupulous credit providers. It was further identified that the over-indebted consumers lacked personal financial management knowledge.

It is therefore recommended that:

a. The Department of Education and Training (DET) should collaborate with the NCR and include personal financial management subject as part of the curriculum from the primary level of schooling. Life orientation that is offered at high school level should also incorporate financial management skills. 
b. Personal financial management education should be made compulsory in adult learning centres.

c. Consumers should attend financial wellness programmes that may be offered in their respective environments.

\subsection{Recommendations for the NCR}

In the literature study and the empirical results, it was noted that some of the registered debt counsellors were not adequately trained. The NCR was not appropriately monitoring and supporting both the debt counsellors and the credit providers as mandated by the NCA. The NCR was not responding to the complaints raised by some of the debt counsellors regarding lack of cooperation from some of the credit providers. The NCR was also taking time to register the transfer of consumers from one debt counsellor to another and there was a delay in the issuing of clearance certificates.

It is therefore recommended that the NCR:

a. reassess the training needs of debt counsellors;

b. formalise the training of prospective debt counsellors;

c. appraise performance of debt counsellors;

d. monitor and support debt counsellors and the credit providers;

e. accelerate the transfer of consumers from one debt counsellor to another;

f. evaluate reasons for the increase of amount that the consumers owe; and

g. issue clearance certificates to consumers as soon as they have fully paid their debts.

\subsection{Recommendations for further research}

On reflecting on the results of the study, the following are suggested for future research:

a. The replication of the study with other samples is recommended. This study was limited to over-indebted consumers in Gauteng only. There is a need for a cross-province assessment study, to identify the common effect of the debt counselling process on all over-indebted consumers in South Africa.

b. Since the study found that most of the over-indebted consumers were working and earning a salary, it is recommended that further research be conducted to explore, firstly, consumers' performance (while over-indebted) in their employment and, secondly, the possibilities of employers' involvement in assisting their employees (who are over-indebted).

c. Although there was a measurable response rate of $61 \%$ from the second phase of the study, future research can investigate the means of increasing the response rate.

d. An investigation of individuals who are not over-indebted or who do not become overindebted can also be conducted to determine how they manage their finances and prevent over-indebtedness.

e. Furthermore, the existence of spurious debt counsellors and their practices could be investigated. 


\section{CONCLUSION}

This article reported on the possibility of obtaining data from two sample populations (debt counsellors and rehabilitated consumers) and it identified a need for personal financial management for both debt counsellors and consumers.

Debt counselling services appeared to have a positive effect on the financial well-being of consumers, because the services were found to be assisting consumers in paying off their debts and recovering from all their debt problems, including improving their credit ratings. After receiving debt counselling services, some consumers were able to save money and manage their finances better. However, the findings of the study identified the need for debt counselling to improve.

\section{LIST OF REFERENCES}

Bailey, C. (2013). Unsecured loans risky for those in debt. Retrieved from:

http://www.iol.co.za/business/news/unsecured-loans-risky-for-those-in-debt. (Accessed 19 April 2014).

Bester. L. (2013). Lifeline for over-indebtedness. Retrieved from:

http://www.fin24.com/Debt/News/Lifeline-for-over-Indebtedness. (Accessed 25 August 2014).

Boone, L.E., Kurtz, D.L. \& Hearth, D. (2000). Planning your financial future, $2^{\text {nd }}$ edition. Oak Brook: Dryden Press.

Business Enterprises. (2012). An assessment of debt counselling in South Africa. Retrieved from: http://www.ncr.org.za/publications/DC\%20Impact\%20Assessment\%20Report-2012.pdf. (Accessed 2 May 2013).

Cameron, B. (2012). Govt will nudge you to save. Retrieved from:

http://www.iol.co.za/business/personal-finance/financial-planning/investments/govt-will-nudgeyou-to-save-1.1325885 (Accessed 18 April 2013).

Consumer and Financial Literacy Taskforce. (2010). The consumer experience. Retrieved from: http://cfltaskforce.treasury.gov.au/content/_download/DiscussionPaper/html/06Chapter2.asp. (Accessed 16 July 2013).

Consumer Financial Vulnerability Index for South Africa. (2013). Financial advisers could be your lifeline. Retrieved from: http://www.bizcommunity.com/Article/196/518/100071.html. (Accessed 25 August 2014).

Creswell, J.W. (2007). Qualitative inquiry and research design: Choosing among five approaches, $3^{\text {rd }}$ edition. London: Sage.

Daily Industry News. (2012). Summit reviewed indebtedness in South Africa. Retrieved from: http://www.bizcomm.com. (Accessed 31 0ctober 2012).

Davel G. (2010). NCR's success stories. Retrieved from: www.ncr.org.za. (Accessed 15 March 2012).

Debt Counselling Help South Africa. (2009). Debt counselling in South Africa. Retrieved from: http:www.debtcounsellinghelpsa.za. (Accessed 20 November 2010). 
De Waal, M. (2013). South Africans are sinking under debt-and the credit amendment bill won't pull us out. Retrieved from: http://www.dailymaverick.co.za/article/2013-06-04-south-africans-aresinking-under-debt-and-the-credit-amendment-bill-wont-pull-us-out. (Accessed 16 July 2013).

De Wet, K. (2011). What is debt counselling? Retrieved from:

http://www.callupcontact.com/b/businessprofile/Karlien_De_Wet_Debt_Counselling/495500. (Accessed 10 December 2011).

Dialtax. (2012). The importance of personal finance. Retrieved from:

http://www.dialtax.ca/pdf/the-importance-of-financial-planning.pdf. (Accessed 13 April 2013).

dti (Department of Trade and Industry). (2003). Credit law review: Summary of findings of the Technical Committee. Retrieved from:

http://www.ncr.org.za/publications/Background_NCA_docs/Summary\%20of\%20Findings.pdf. (Accessed 21 November 2011).

Family Economics and Financial Education. (2010). Life cycle of financial planning. Retrieved from: http://www.thedaleyjournal.com/coursefiles/pftt/Life_Cycle_of_Financial_Planninginfosheet.pdf. (Accessed 15 July 2013).

Gordon, G.M. (2010). The life cycle of financial planning. Retrieved from:

http://eruralfamilies.uwagec.org/ERFLibrary/Readings/LifeCycleofFinancialPlanning.pdf. (Accessed 15 July 2013).

Grayson, D. (2004). Some myths and legends in quantitative psychology. Understanding statistics, 3 (2), pp. 101-134.

Groenewald, C. (2010). Debt counselling training in need of serious restructuring according to research. Retrieved from: www.compuscanacademy.co.za/press-room/250-debt-counsellingtraining-in-need. (Accessed 20 November 2011).

Lusardi, A. \& Mitchell, 0.S. (2006). Financial literacy \& planning: implications for retirement wellbeing. Retrieved from: http://www.dartmouth.edu/ alusardi/Papers/FinancialLiteracy.pdf. (Accessed 5 September 2014).

Moneyweb. (2013). Capitec now offers R230 000 unsecured loan. Retrieved from:

http://www.moneyweb.co.za/moneyweb-financial/capitec-now-offers-r230-000-unsec. (Accessed 19 April 2014).

MSG (Management Study Guide). (2013). Financial planning-Definition, objectives and importance. Retrieved from: http://www.managementstudyguide.com/financial-planning.htm. (Accessed 16 May 2013).

National Credit Act Info. (2012). Knowing the importance of personal finance management. Retrieved from: http://www.nationalcreditactinfo.co.za/knowing-the-importance-of-personal-financemanagement. (Accessed l May 2013).

NCR (National Credit Regulator). (2012). Consumer credit market report. Retrieved from: www.ncr.org.za (Accessed 29 October 2012).

NCR (National Credit Regulator). (2013). Consumer credit market report. Retrieved from: www.ncr.org.za (Accessed 4 November 2013).

NCR (National Credit Regulator). (2014). Consumer credit market report. Retrieved from: www.ncr.org.za. (Accessed 14 April 2014). 
Norvilitis, J.M., Merwin, M.M, Osberg, T.M, Roehling, P.V, Young, P. \& Kamas, M.M. (2006). Factors, money attitudes, financial knowledge and credit debt in college students. JApp. Soc. Psychology, 36(6), pp. 1395-1413.

Pallant, J. (2010). SPSS Survival Manual: A step by step guide to data analysing using SPSS, $4^{\text {th }}$ edition. New York: McGraw Hill.

Pritchard, J. (2013). Unsecured loans - Definition of unsecured loans. Retrieved from: http://banking.about.com/od/loans/g/unsecured.htm. (Accessed 19 April 2014).

Roestoff, M., Haupt, F., Coetzee, H. \& Erasmus, M. (2009). The debt counselling process: Closing the loopholes in the National Credit Act 34 of 2005. Potchefstroom Electronic, 12(4), pp. 246-305.

Serrano, P. (2012). The 3 life cycle stages and how they affect your finances. Retrieved from: http://personalfinancemastery.com/2012/the-3-life-cycle-stages-and-how-they. (Accessed 5 July 2013).

Stats SA (Statistics South Africa). (2012). Census 2011 Results by Province. Retrieved from: http://www.bdlive.co.za/national/2012/10/31/census-millions-in-exodus-to-sas-richerprovinces. (Accessed 31 0ctober 2012).

Thekiso, T.A. (2011). Management performance measurement of business school educated managers in the North West and Vaal Triangle Areas. Unpublished PhD thesis. Potchefstroom: University of North West.

Theobald, S \& Dick, W. (2013). The rise and rise of unsecured lending. Retrieved from: http://www.bdlive.co.za/business/financial/2013/06/07/the-rise-and-rise-of-unsecured. (Accessed 5 July 2013).

Viswanand, V. (2013). Better retirement planning. Retrieved from:

http://www.thehindubusinessline.com/opinion/better-retirement-planning/article 4724678.ece. (Accessed 15 May 2013).

Wang, J.J. (2010). Credit counselling to help debtors regain footing. Journal of Consumer Affairs, 44(1), pp. $44-69$.

Wealth-Steps.com. (2012). The importance of personal finance and why you need to get it. Retrieved from: http://www.wealth-steps.com/importance-of-personal-finance.html. (Accessed 12 April 2013).

Welman, J.C., Kruger, F. \& Mitchell, B. (2010). Research methodology, $3^{\text {rd }}$ edition. Cape Town: Oxford. Wright, D.B. (2003). Making friends with your data: improving how statistics are conducted and reported. British Journal of Education Psychology, 73, pp. 123-136. 